\title{
SISTEM PENDUKUNG KEPUTUSAN \\ EVALUASI KINERJA PRAMUNIAGA TOSERBA YOGYA CIWALK MENGGUNAKAN METODE WEIGHTED PRODUCT
}

\author{
Phitsa Mauliana $^{1)}$, Wildan Wiguna', Dimas Widyaman ${ }^{3)}$ \\ Prodi. Manajemen Informatika ${ }^{12)}$, Prodi Sistem Informasi ${ }^{3)}$ \\ AMIK BSI Bandung ${ }^{1)}$, AMIK BSI Tasikmalaya ${ }^{2)}$ Universitas BSI Bandung $^{3)}$ \\ phitsa.phu@bsi.ac.id ${ }^{1)}$, wildan.wwg@bsi.ac.id ${ }^{2)}$, dimaswidyaman.dw@ gmail.com ${ }^{3)}$
}

\begin{abstract}
ABSTRAK
Pramuniaga merupakan karyawan atau karyawati yang bekerja pada sebuah perusahaan dagang. Pramuniaga yang kompeten dan profesional akan bekerja untuk meningkatkan kinerja dan omzet dari perusahaan. Seorang Pramuniaga melakukan penjualan barang dagangan kepada konsumen yang membutuhkannya. Toserba Yogya Ciwalk merupakan suatu perusahaan yang bergerak di bidang penjualan dengan format supermarket dan department store. Pramuniaga yang kompeten dan profesional dalam melayani konsumen sangat menetukan keberhasilan penjualan dari perusahaan tersebut. Namun pihak manajemenen kesulitan dalam melakukan evaluasi kinerja Pramuniaga menggunakan beberapa standar atau kriteria penilaian yang diinginkan. Proses evaluasi kinerja masih menggunakan formulir kertas, sehingga banyak data penilaian kinerja Pramuniaga yang tercecer. Kemudian belum adanya suatu metode yang tepat untuk diterapkan pada proses evaluasi kinerja Pramuniaga pada Toserba Yogya Ciwalk. Tujuan dari penelitian ini yaitu membangun suatu Sistem Pendukung Keputusan untuk evaluasi kinerja terhadap Pramuniaga pada Toserba Yogya Ciwalk menggunakan metode Weighted Product. Hasil penelitian menunjukkan bahwa Sistem Pendukung Keputusan memberikan kemudahan bagi pihak manajemen khususnya personalia dalam melakukan penilaian kinerja terhadap Pramuniaga sesuai dengan standar/kriteria yang telah ditentukan. Sistem Pendukung Keputusan tersebut berhasil dibangun menggunakan Web Programming berbasis objek. Kemudian metode Weighted Product yang diterapkan sangat tepat untuk menghitung peringkat dari kinerja Pramuniaga di Toserba Yogya Ciwalk.
\end{abstract}

\section{Kata Kunci: Sistem Pendukung Keputusan, Metode Weighted Product, Evaluasi Kinerja Pramuniaga.}

\section{PENDAHULUAN}

Seorang Pramuniaga melakukan penjualan barang dagangan kepada konsumen yang membutuhkannya. Beberapa tugas dari Pramuniaga yaitu membantu konsumen menemukan barang yang dibutuhkan, menawarkan panduan memilih barang yang sesuai, serta memproses pembayaran pelanggan. Kemudian Pramuniaga juga memberitahukan kepada pelanggan mengenai penjualan, promosi, insentif, dan kebijakan tentang cara pembayaran maupun pengembalian (La Bella, 2017: 17).

Pramuniaga adalah karyawan dan/atau karyawati yang bekerja pada sebuah perusahaan dagang. Pramuniaga merupakan salah satu jenis profesi, maka Pramuniaga pun dituntut untuk memiliki kinerja yang profesional. Pramuniaga yang kompeten dan profesional sesungguhnya akan bekerja untuk meningkatkan kinerja dirinya. Sehingga hasilnya akan berimbas kepada peningkatan kinerja dan omzet dari perusahaan (Prasetyadi, 2017: 15).

Toserba Yogya Ciwalk merupakan perusahaan yang bergerak di bidang penjualan yaitu perusahaan ritel modern asli Indonesia dengan format supermarket dan department store. Pramuniaga yang kompeten dan profesional dalam melayani konsumen ataupun pelanggan sangat menetukan keberhasilan penjualan dari perusahaan tersebut. Sehingga toserba Yogya Ciwalk dapat menghadirkan solusi berbelanja yang lebih mudah untuk memenuhi kebutuhan sehari-hari bagi pelanggan.

Terdapat beberapa kendala dari hasil observasi yang telah dilakukan pada Toserba 
Yogya Ciwalk dalam menilai atau mengevaluasi kinerja Pramuniaga. Pihak manajemenen kesulitan dalam melakukan evaluasi kinerja Pramuniaga menggunakan beberapa standar atau kriteria penilaian yang diinginkan. Proses evaluasi kinerja tersebut masih menggunakan formulir kertas, sehingga banyak data penilaian kinerja Pramuniaga yang tercecer. Kemudian belum adanya suatu metode yang tepat untuk diterapkan pada proses evaluasi kinerja Pramuniaga pada Toserba Yogya Ciwalk. Hal tersebut mengakibatkan kurangnya relevansi penilaian yang dilakukan oleh pihak manajemen. Sehingga proses pengambilan keputusan evaluasi kinerja terhadap Pramuniaga maupun alternatif yang tersedia masih kurang terorganisir.

Sistem Pendukung Keputusan (SPK) adalah suatu sistem informasi spesifik yang ditujukan untuk membantu manajemen dalam mengambil keputusan berkaitan dengan persoalan yang bersifat semi terstruktur. Sistem ini memiliki fasilitas untuk menghasilkan berbagai alternatif yang secara interaktif digunakan oleh pengguna (Latif, Jamil, \& Abbas, 2018: 3; Nofriansyah \& Defit, 2017: 2). Sistem Pendukung Keputusan biasanya dibangun untuk mendukung solusi atas suatu masalah atau peluang. Sedangkan aplikasi Sistem Pendukung Keputusan digunakan dalam pengambilan keputusan menggunakan konsep CBIS (Computer Based Information Systems) yang fleksible, interaktif, dan dapat diadaptasi. Aplikasi tersebut dikembangkan untuk mendukung solusi atas masalah manajemen spesifik yang tidak tersetruktur (Nofriansyah, 2018: 1).

Metode Weighted Product (WP) merupakan suatu metode di dalam penentuan sebuah keputusan (Nofriansyah, 2014: 47). Metode Weighted Product merupakan bagian dari konsep Multi Criteria Decision Making (MCDM) yang merupakan teknik pengambilan keputusan dari beberapa alternatif yang ada. Dengan metode ini diharapkan dapat dikembangkan sebuah perangkat lunak Sistem Pendukung Keputusan yang dapat digunakan oleh suatu instansi. Sehingga akan menjadi alternatif pemilihan dan memberikan nilai bobot pada perbandingan alternatif dan kriterianya yang sudah ditentukan oleh perusahaan (Sari, 2018: 57).

Dari permasalah yang telah diapaparkan sebelumnya, maka penelitian ini berfokus pada proses evaluasi kinerja Pramuniaga di Toserba Yogya Ciwalk. Kemudian solusi yang diajukan pada kasus yang diteliti akan diterapkan metode Weighted Product untuk melengkapi pembuatan perangkat lunak atau aplikasi Sistem Pendukung Keputusan. Sehingga tujuan dari penelitian ini dapat terangkum ke dalam Sistem Pendukung Keputusan menggunakan metode Weighted-Product untuk evaluasi kinerja Pramuniaga pada Toserba Yogya Ciwalk.

\section{METODE PENELITIAN}

\subsection{Sistem Pendukung Keputusan}

Sistem Pendukung Keputusan (SPK) menggunakan model analitik untuk membantu pengguna dalam mendapatkan wawasan terhadap situasi permasalahan, memeriksa solusi alternatif, dan merekomendasikan tindakan yang tepat (Reynolds, 2016: 5).

Sistem Pendukung Keputusan merupakan pengembangan lebih lanjut dari sistem informasi manajemen terkomputerisasi yang dirancang sedemikian rupa sehingga bersifat interaktif dengan penggunanya. Sifat interaktif ini dimaksudkan untuk memudahkan integrasi antara berbagai komponen dalam proses pengambilan keputusan seperti prosedur, kebijakan, teknik analisis, serta pengalaman dan wawasan menajerial guna membentuk suatu kerangka keputusan yang bersifat fleksibel (Sari, 2018: 1-2).

Model yang terkenal dikembangkan oleh Simon (1997) dalam Stair dan Reynolds (2016: 291) membagi fase pengambilan keputusan dari proses pemecahan masalah menjadi tiga tahap yaitu kecerdasan (intelligence), perancangan (design), dan pemilihan (choice). Model ini kemudian dimasukkan oleh Huber (1980) dalam Stair dan Reynolds (2016: 291) ke dalam model yang diperluas dari keseluruhan proses pemecahan masalah menjadi lima fase yang dapat dilihat pada gambar 1 . 


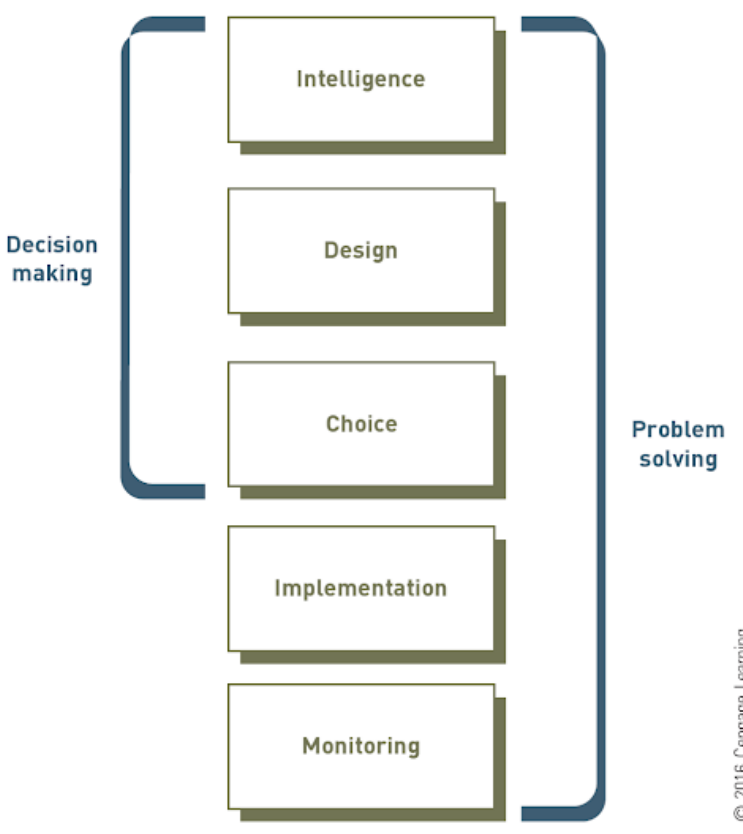

Gambar 1. Fase Pengambilan Keputusan \& Pemecahan Masalah.

Sumber: Stair dan Reynolds (2016: 291)

Pada gambar 1 menunjukkan fase/tahap pengambilan keputusan yang terkait dengan proses pemecahan masalah yang dapat dijelaskan menurut Stair dan Reynolds (2016: 191-292) sebagai berikut:

1. Tahap kecerdasan (intelligence), tahap pertama pengambilan keputusan yaitu mengidentifikasi dan menentukan potensi masalah atau peluang.

2. Tahap perancangan (design), tahap yang kedua dari pengambilan keputusan yaitu mengembangkan solusi alternatif untuk masalah dan mengevaluasi kelayakannya.

3. Tahap pemilihan (choice stage), tahap ketiga pengambilan keputusan yaitu membutuhkan pemilihan suatu tindakan.

4. Tahap penerapan (implementation), yaitu tahap pemecahan masalah dengan solusi yang diberlakukan.

5. Tahapan pemantauan (monitoring), tahap akhir dari proses pemecahan masalah yaitu pihak pengambil keputusan mengevaluasi pelaksanaannya.

\subsection{Metode Weighted Product}

Metode Weighted Product merupakan sebuah metode di dalam penentuan sebuah keputusan dengan cara perkalian untuk menghubungkan rating atribut, dimana rating setiap atribut harus dipangkatkan terlebih dahulu dengan bobot atribut yang bersangkutan. Proses tersebut sama halnya dengan proses normalisasi (Nofriansyah, 2014: 47).

$$
\text { Langkah-langkah metode Weighted }
$$

Product menurut Sari (2018: 59-60), antara lain:

1. Menentukan kriteria-kriteria yang akan dijadikan acuan dalam pengambilan keputusan.

2. Menentukan rating kecocokan setiap alternatif pada setiap kriteria.

3. Menentukan bobot preferensi tiap kriteria.

4. Mengalikan seluruh atribut bagi sebuah alternatif dengan bobot sebagai pangkat positif untuk atribut keuntungan (benefit) dan bobot berpangkat negatif untuk atribut biaya (cost).

Rumus untuk menghitung nilai preferensi terhadap alternatif (Ai) sebagai berikut:

$$
S_{i}=\prod_{j=1}^{n} x_{i j}{ }^{w j}
$$

\section{Keterangan:}

S : menyatakan preferensi alternatif yang dianalogikan sebagai vector $\mathrm{S}$

$\mathrm{x}$ : menyatakan nilai kriteria

w : menyatakan bobot kriteria

i : menyatakan alternatif

$\mathrm{j}$ : menyatakan kriteria

$\mathrm{n}$ : menyatakan banyaknya kriteria

5. Hasil perkalian tersebut dijumlahkan untuk menghasilkan nilai vector $\mathrm{V}$ untuk setiap alternatif. Nilai vector $\mathrm{V}$ dapat dihitung dengan rumus:

$$
V_{i}=\frac{\prod_{j=1}^{n} x_{i j}{ }^{w j}}{\prod_{j=1}^{n}\left(x_{j}\right)^{w j}}
$$

Keterangan:

$\mathrm{V}$ : menyatakan preferensi alternatif yang dianalogikan sebagai vector $\mathrm{V}$

$\mathrm{x}$ : menyatakan nilai kriteria

w : menyatakan bobot kriteria

i : menyatakan alternatif

$\mathrm{j}$ : menyatakan kriteria 
$\mathrm{n}$ : menyatakan banyaknya kriteria

6. Mencari nilai alternatif dengan melakukan langkah yang sama seperti pada langkah satu, hanya saja menggunakan nilai tertinggi untuk setiap atribut manfaat (benefit) dan nilai terendah untuk atribut biaya (cost).

7. Membagi nilai $\mathrm{V}$ bagi setiap atribut dengan nilai standar.

8. Mencari nilai alternatif ideal yakni dengan merangking nilai vector $\mathrm{V}$, sekaligus membuat kesimpulan sebagai tahap akhir.

\section{HASIL DAN PEMBAHASAN}

\subsection{Analisis}

\subsubsection{Proses Bisnis Sistem}

Toserba Yogya Ciwalk melakukan evaluasi kinerja terhadap Pramuniaga setiap 6 bulan sekali sesuai dengan kontrak kerja.

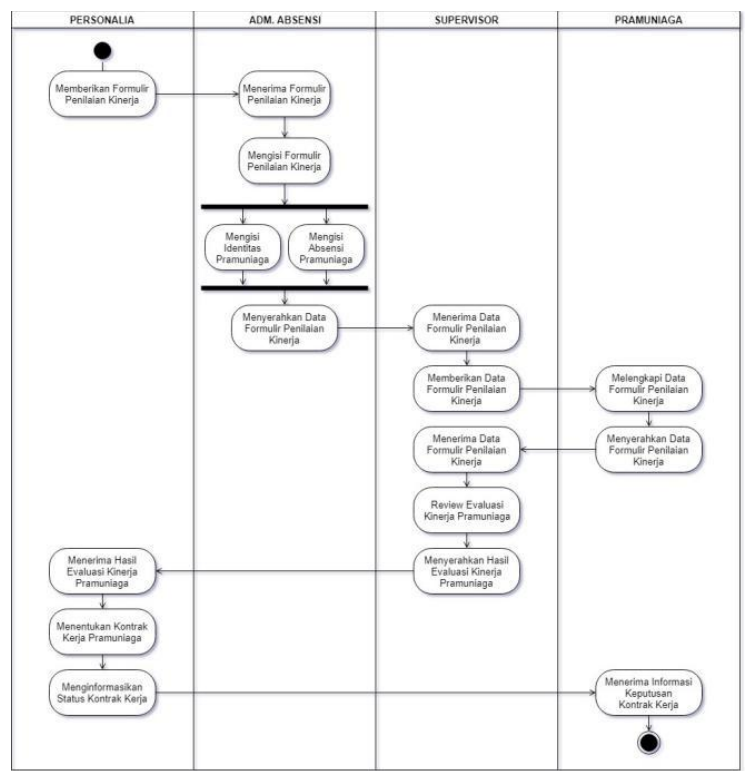

Gambar 2 Activity Diagram Evaluasi Kinerja Pramuniaga

Pada gambar 2 menunjukkan Activity Diagram evaluasi kinerja Pramuniaga. Proses evaluasi diawali ketika bagian Personalia menyerahkan formulir penilaian kinerja karyawan yang kosong kepada Adm. Absensi untuk mengisi identitas Pramuniaga beserta penilaian kriteria kedisiplinan. Kemudian formulir tersebut diserahkan kepada Supervisor untuk melengkapi data penilaian kriteria pelaksanaan tugas dan sifat kepribadian. Proses evaluasi akan dianggap selesai jika hasil evaluasi diserahkan kembali kepada Personalia untuk menentukan kelanjutan status kontrak kerja dari Pramuniaga.

\subsubsection{Spesifikasi Dokumen Sistem Berjalan}

Rincian setiap dokumen dari sistem yang digunakan pada tempat riset antara lain:

1. Dokumen : Formulir Penilaian Kinerja

Fungsi : Menilai kinerja Pramuniaga

Sumber : Personalia

Tujuan : Supervisor \& Adm. Absensi

Media : Kertas

Jumlah : 1 halaman

Frekuensi : 6 bulan

2. Dokumen : Standar/Kriteria Penilaian

Fungsi : Panduan evaluasi kinerja

Sumber : Personalia

Tujuan : Supervisor \& Adm. Absensi

Media : Kertas

Jumlah : 1 halaman

Frekuensi : Setiap perubahan kebijakan

\subsection{Perancangan}

\subsubsection{Use Case Diagram}

Pemodelan Use Case Diagram rancangan Sistem Pendukung Keputusan digambarkan dalam bentuk sea level untuk overview.

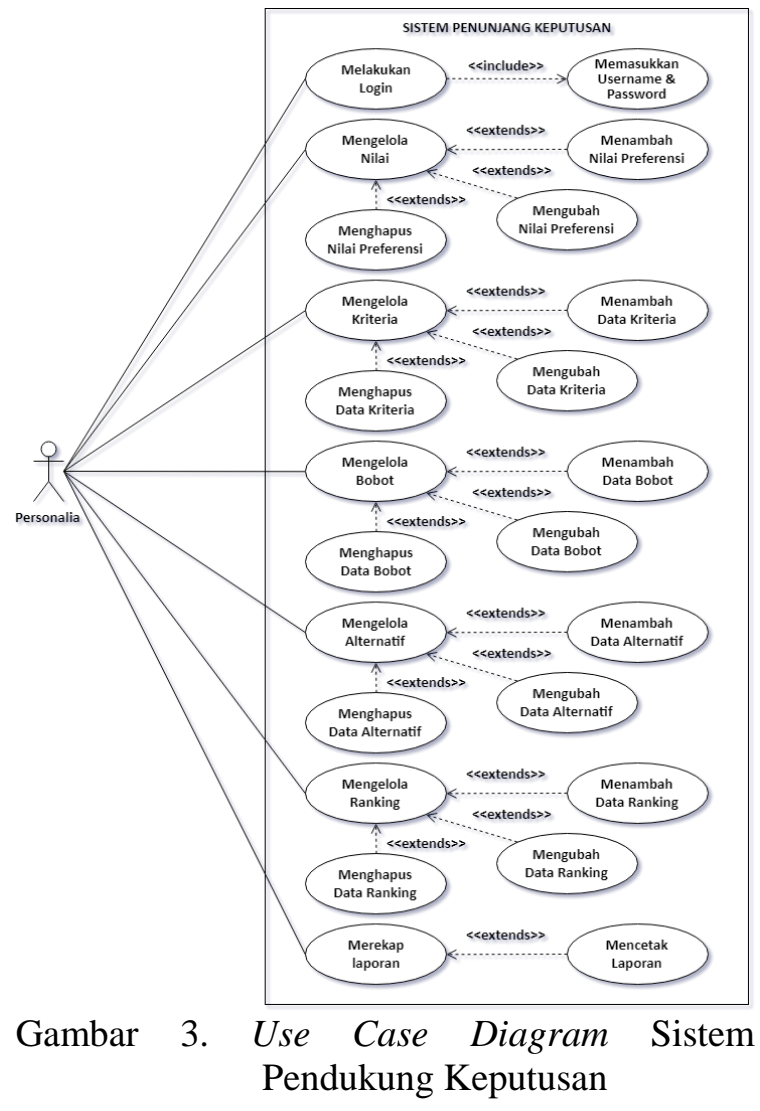


Pada gambar 3 merupakan kegiatan yang dimulai dengan melakukan login, kemudian berlanjut pada mengelola nilai, kriteria, bobot, alternatif, rangking, sampai merekap laporan.

\subsubsection{Activity Diagram}

Seluruh aktivitas terhadap Sistem Pendukung Keputusan dilakukan oleh Personalia yang digambarkan dengan Activity Diagram.

\section{Activity Diagram Melakukan Login}

Proses login Personalia digambarkan dengan rancangan Activity Diagram berikut ini:

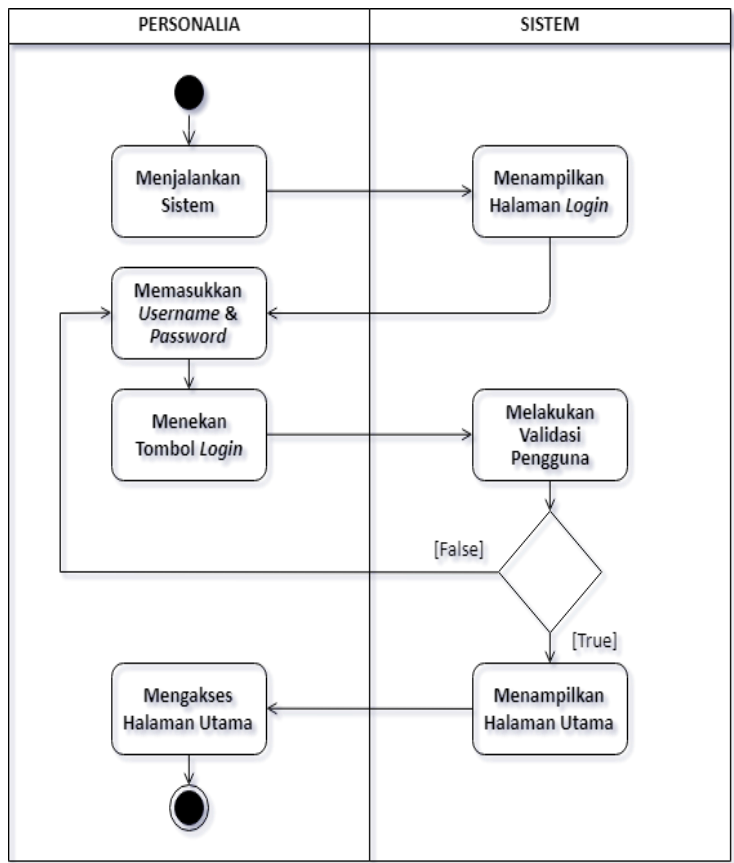

Gambar 4. Activity Diagram Melakukan Login

Pada gambar 4 dapat dijelaskan bahwa Personalia harus melakukan login dengan memasukkan username dan password.

\section{Activity Diagram Mengelola Nilai}

Pengelolaan nilai preferensi digambarkan dengan Activity Diagram sebagai berikut:

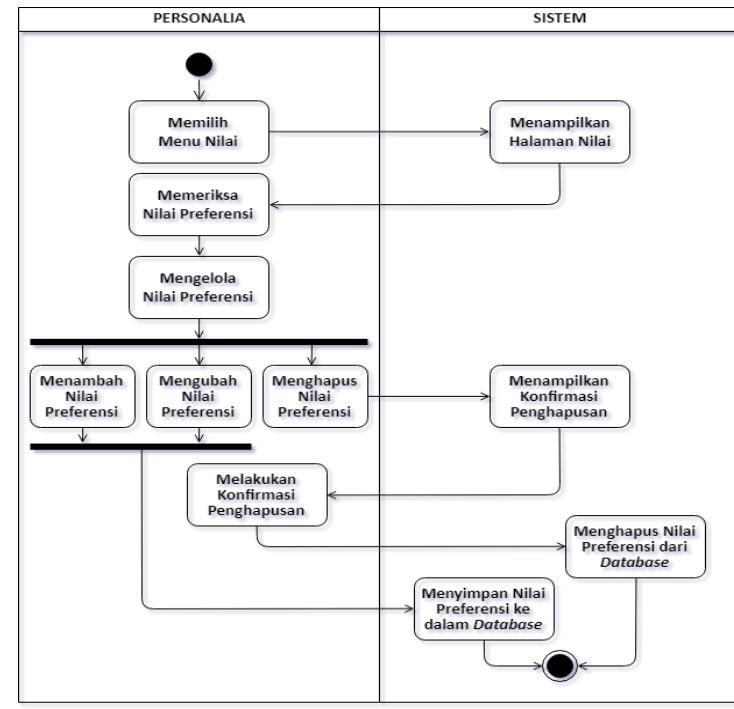

Gambar 5. Activity Diagram Mengelola Nilai

Pada gambar 5 dapat dijelaskan bahwa bagian Personalia mengelola nilai preferensi yang dapat disimpan ke dalam basis data. Data nilai tersebut merupakan angka untuk mengisi dan mendeskripsikan bobot dari kriteria.

3. Activity Diagram Mengelola Kriteria Data kriteria harus dinamis agar dapat disesuaikan dengan kebijakan perusahaan. Sehingga rancangan dari proses atau kegiatan pengelolaan data kriteria dapat digambarkan dengan Activity Diagram sebagai berikut:

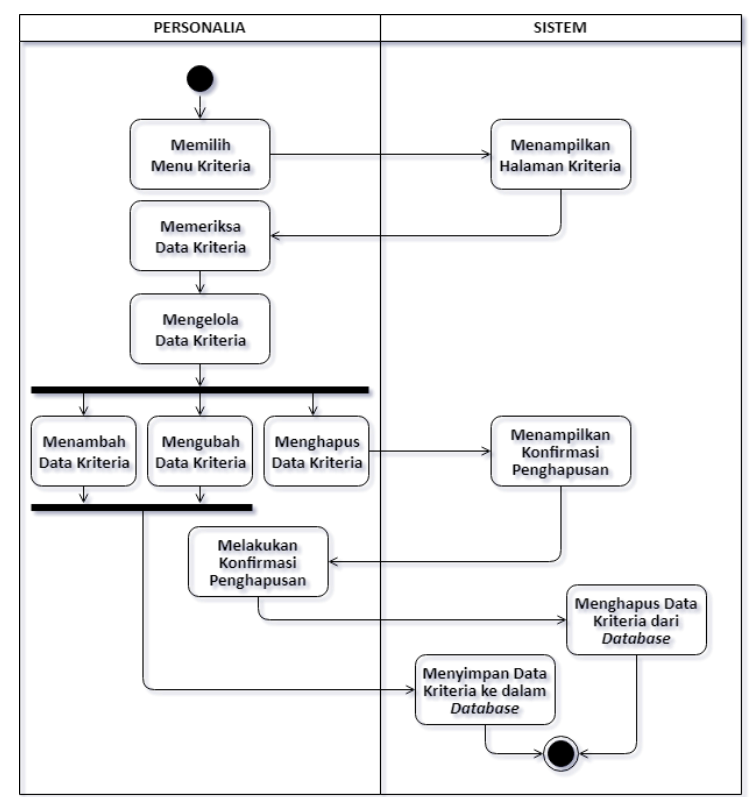

Gambar 6. Activity Diagram Mengelola Kriteria

Pada gambar 6 menunjukkan aktivitas Personalia dalam mengelola standar/kriteria 
penilaian yang telah ditentukan oleh perusahaan antara lain:

a. Pelaksanaan Tugas

1) Penguasaaan Tugas (Kualitas)

2) Penguasaan Tugas (Kuantitas)

3) Tanggung Jawab

4) Penggunaan Fasilitas \& Sarana

b. Disiplin Kerja

1) Kehadiran

2) Keteralambatan

3) Ketaatan

c. Sifat Kepribadian

1) Pengembangan Pribadi

2) Kerjasama \& Komunikasi

4. Activity Diagram Mengelola Bobot

Personalia mengelola bobot yang telah ditetapkan dapat digambarkan dengan Activity Diagram sebagai berikut:

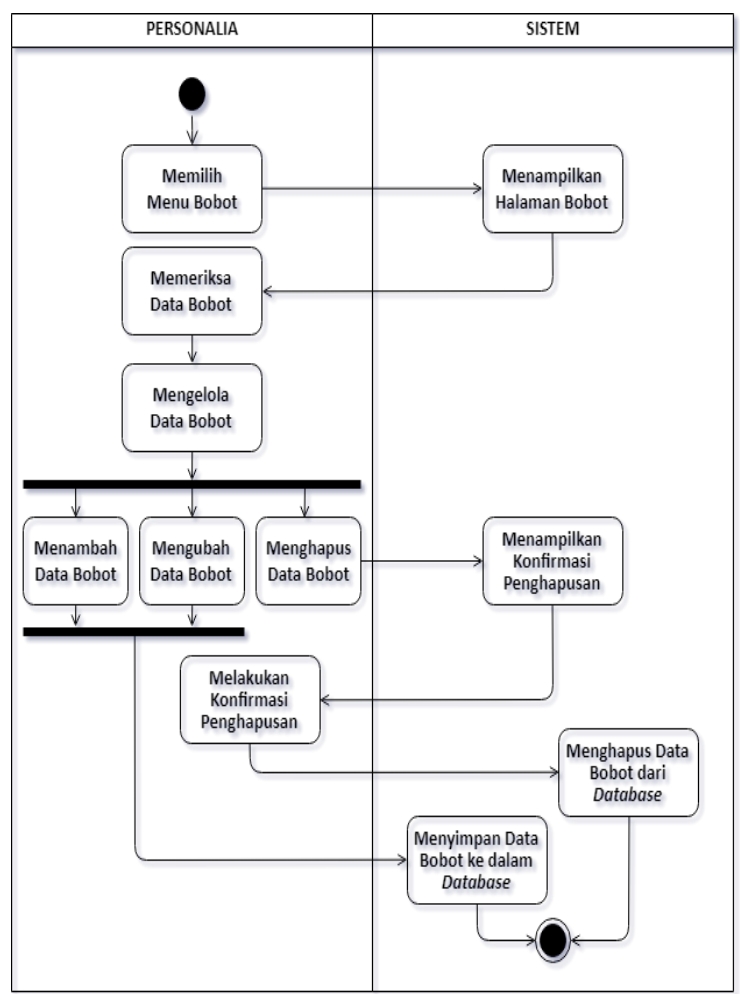

Gambar 7. Activity Diagram Mengelola Bobot

Pada gambar 7 menunjukkan aktivitas Personalia dalam mengelola bobot untuk setiap kriteria penilaian dengan range 1-15.

5. Activity Diagram Mengelola Alternatif

Pengelolaan alternatif yang tidak jarang terjadi turnover dapat digambarkan dengan Activity Diagram berikut ini:

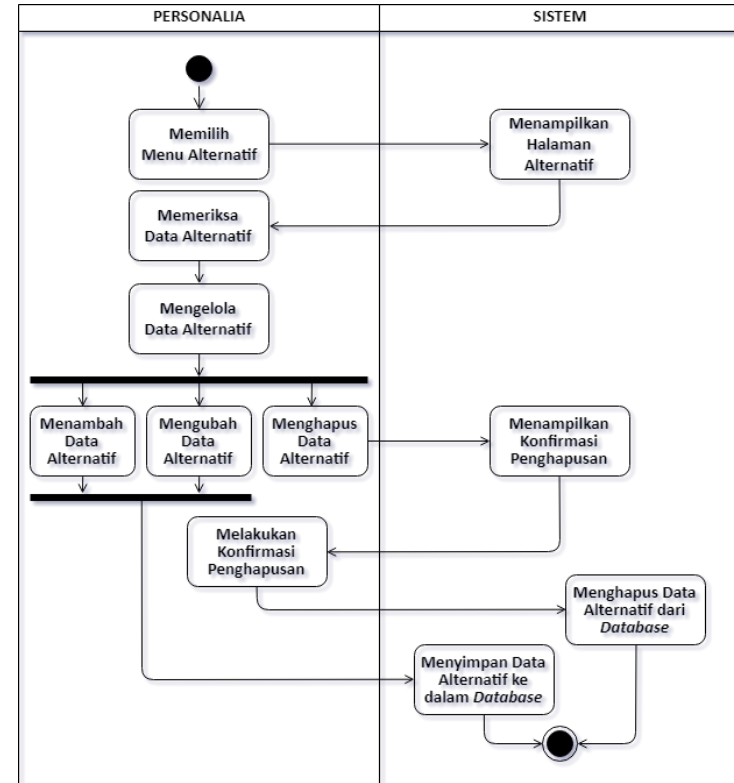

Gambar 8. Activity Diagram Mengelola Alternatif

Pada gambar 8 menunjukkan aktivitas Personalia dalam mengelola alternatif yaitu Pramuniaga yang dievaluasi kinerjanya pada Toserba Yogya Ciwalk.

6. Activity Diagram Mengelola Ranking Aktivitas paling penting yaitu mengelola ranking dengan Activity Diagram berikut ini:

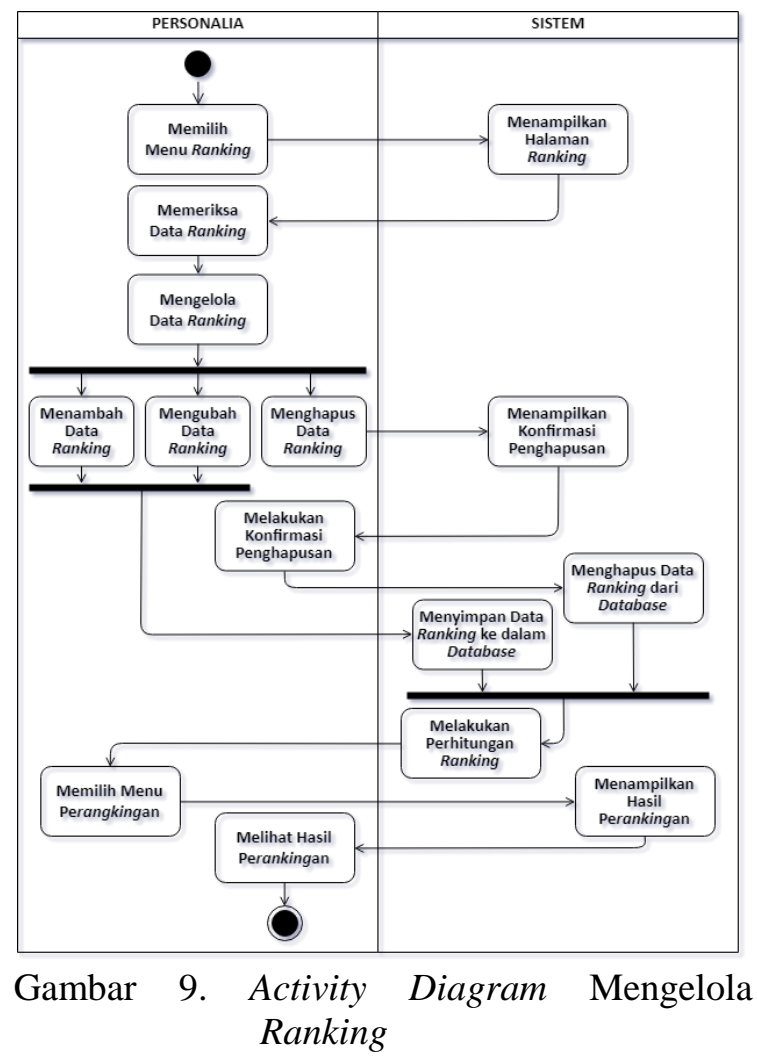


Pada gambar 9 menunjukkan kegiatan dalam menghitung dan menghasilkan ranking.

7. Activity Diagram Merekap Laporan Kegiatan terakhir yaitu merekap laporan evaluasi dengan Activity Diagram berikut ini:

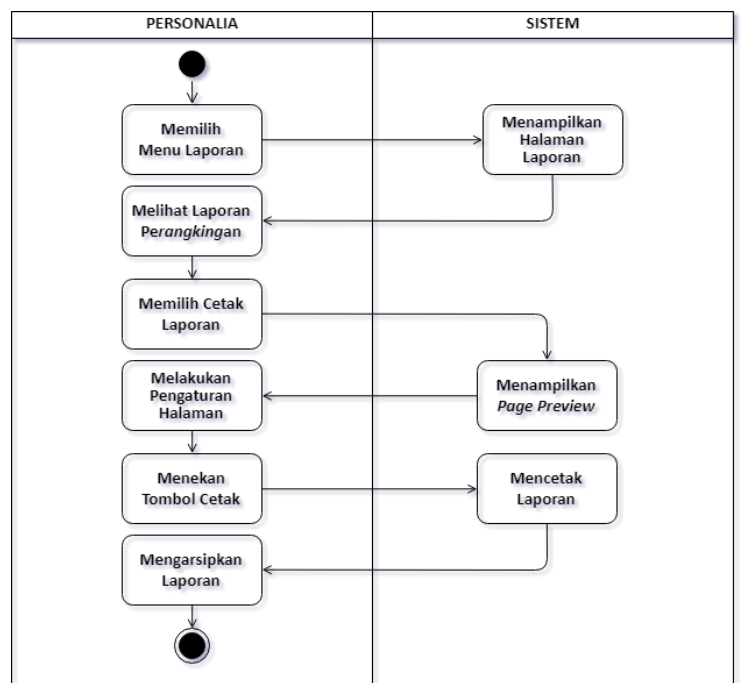

Gambar 10. Activity Diagram Merekap Laporan

Pada gambar 10 yaitu kegiatan merekap laporan untuk dicetak maupun diarsipkan.

\subsubsection{Perancangan Database}

Hubungan/relasi antar tabel atau entitas yang terdapat pada Sistem Pendukung Keputusan beserta atributnya digambarkan menggunakan Entity Relationship Diagram (ERD).

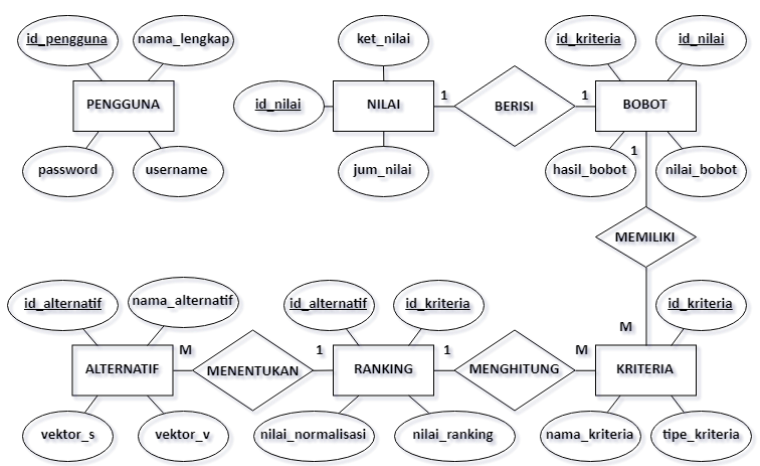

Gambar 11. Entity Relationship Diagram (ERD) Sistem Pendukung Keputusan

Pada gambar 11 merupakan relasi antar entitas yang dapat dijelaskan sebagai berikut:

1. Relasi satu entitas Nilai berisi satu entitas Bobot.
2. Relasi banyak entitas Kriteria memiliki satu entitas Bobot.

3. Relasi satu entitas Ranking dapat menghitung banyak entitas Kriteria, serta satu entitas Ranking menentukan peringkat dari banyak entitas Alternatif.

4. Entitas Pengguna yang dialokasikan bagi Personalia bersifat independent atau berdiri sendiri.

\subsection{Implementasi}

Menampilkan hasil dari pembangunan Sistem Pendukung Keputusan berbasis Web untuk evaluasi kinerja pramuniaga menggunakan metode Weighted Product.

1. User Interface Halaman Login

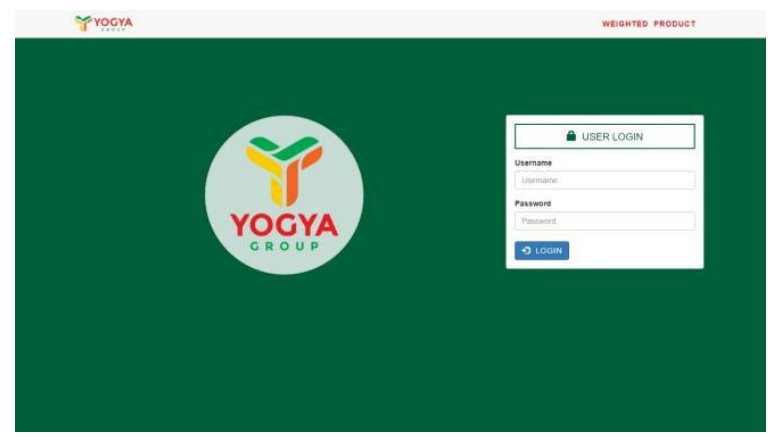

Gambar 12. Tampilan Halaman Login

2. User Interfae Halaman Utama

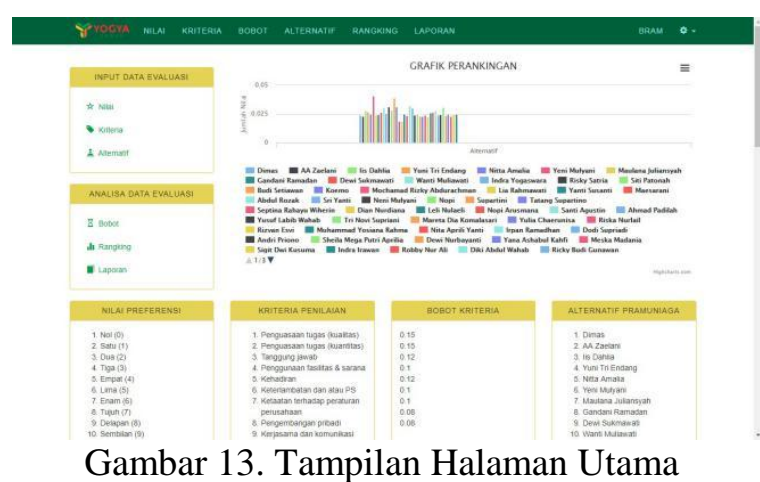

3. User Interface Menu Nilai a. Halaman Data Nilai

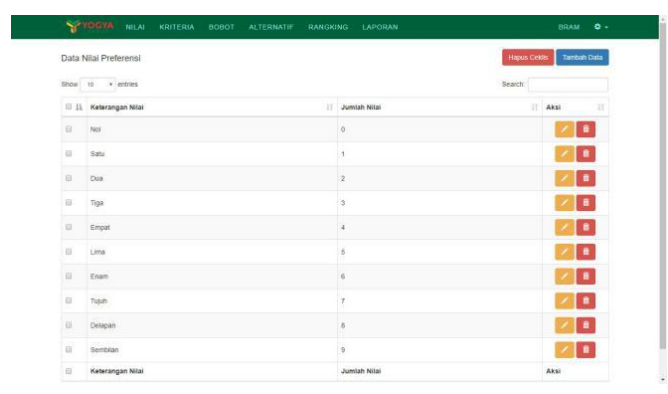


Gambar 14. Tampilan Halaman Data Nilai

b. Halaman Tambah Nilai
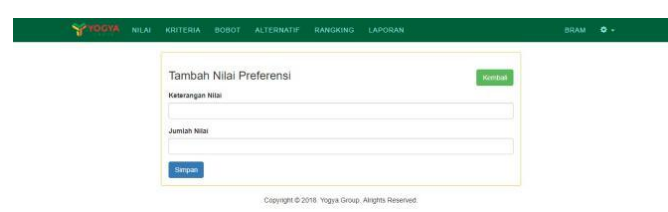

Gambar 15. Tampilan Halaman Tambah Nilai c. Halaman Ubah Nilai

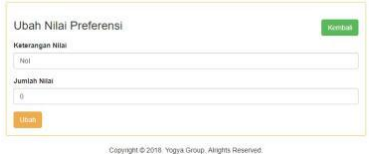

Gambar 16. Tampilan Halaman Ubah Nilai

4. User Interface Menu Kriteria

a. Halaman Data Kriteria

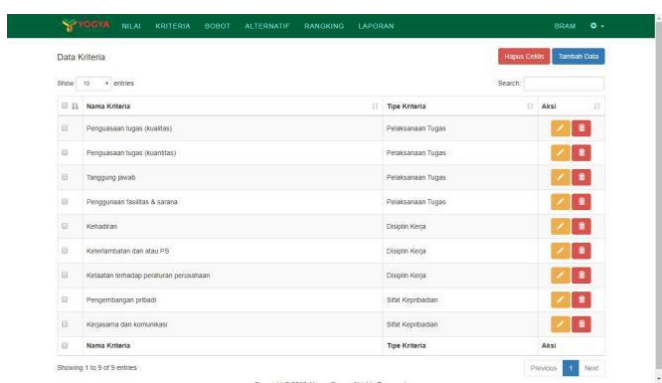

Gambar 17. Tampilan Halaman Data Kriteria

b. Halaman Tambah Kriteria
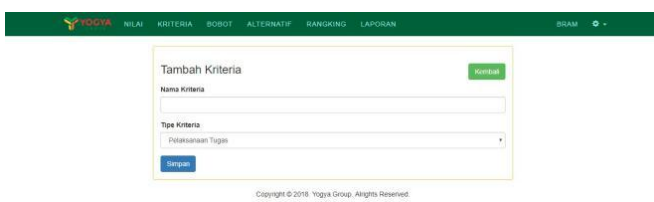

Gambar 18. Tampilan Halaman Tambah Kriteria

c. Halaman Ubah Kriteria

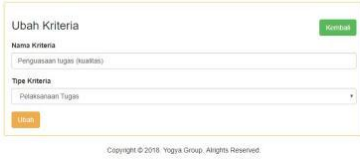

Gambar 19. Tampilan Halaman Ubah Kriteria

5. User Interface Menu Bobot

a. Halaman Data Bobot

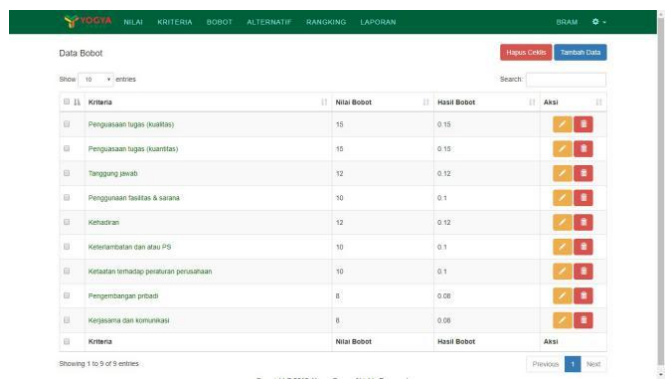

Gambar 20. Tampilan Halaman Data Bobot

b. Halaman Tambah Bobot

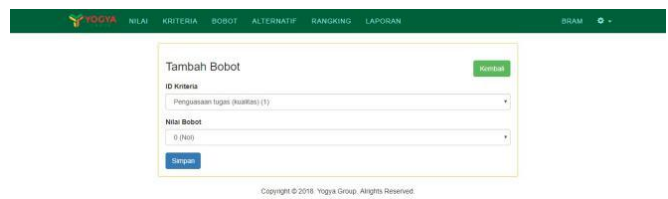

Gambar 21. Tampilan Halaman Tambah Bobot c. Halaman Ubah Bobot

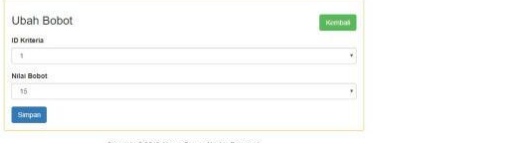


Gambar 22. Tampilan Halaman Ubah Bobot

6. User Interface Menu Alternatif a. Halaman Data Alternatif

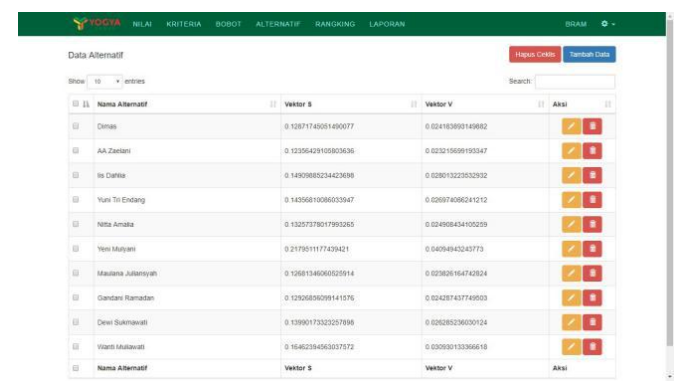

Gambar 23. Tampilan Halaman Data Alternatif

b. Halaman Tambah Alternatif

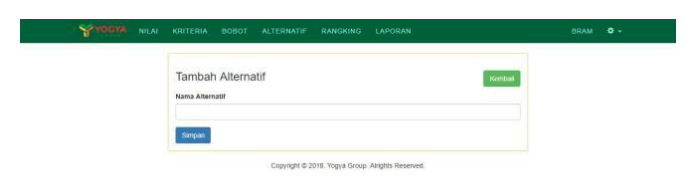

Gambar 24. Tampilan Halaman Tambah Alternatif

c. Halaman Ubah Alternatif

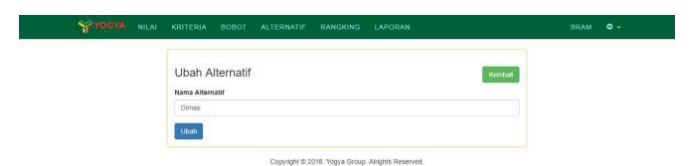

Gambar 25. Tampilan Halaman Ubah Alternatif

7. User Interface Menu Ranking

a. Halaman Data Ranking

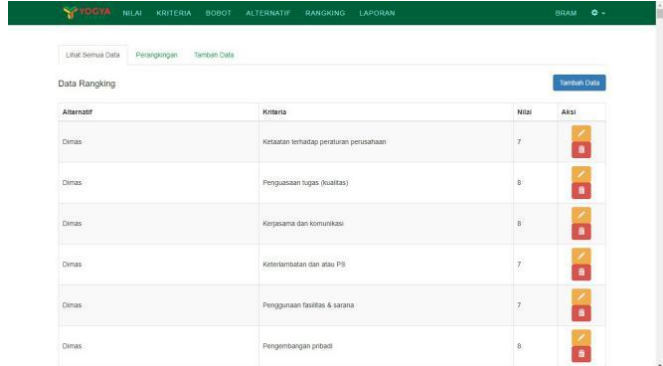

Gambar 26. Tampilan Halaman Data Ranking

b. Halaman Tambah Ranking

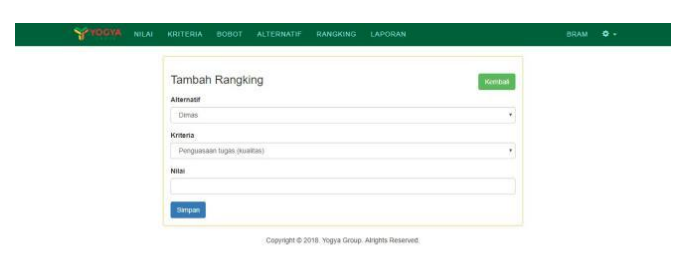

Gambar 27. Tampilan Halaman Tambah Ranking

c. Halaman Ubah Ranking

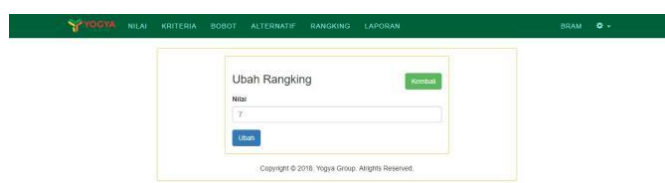

Gambar 28. Tampilan Halaman Ubah Ranking

d. Halaman Perangkingan

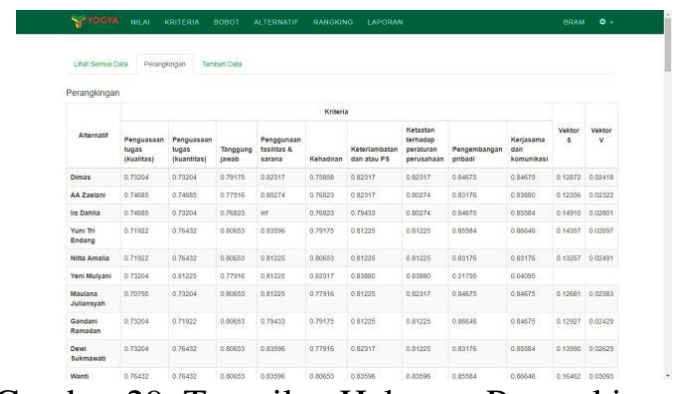

Gambar 29. Tampilan Halaman Perangkingan 
8. User Interface Menu Laporan a. Halaman Laporan Ranking

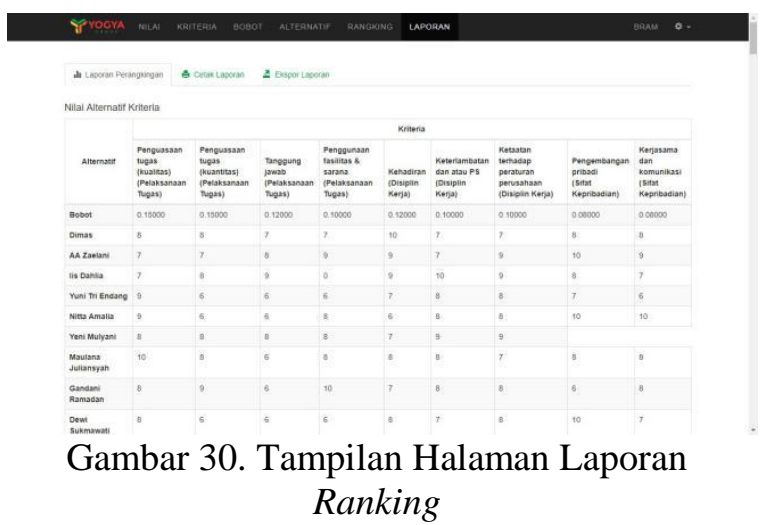

b. Halaman Cetak Laporan

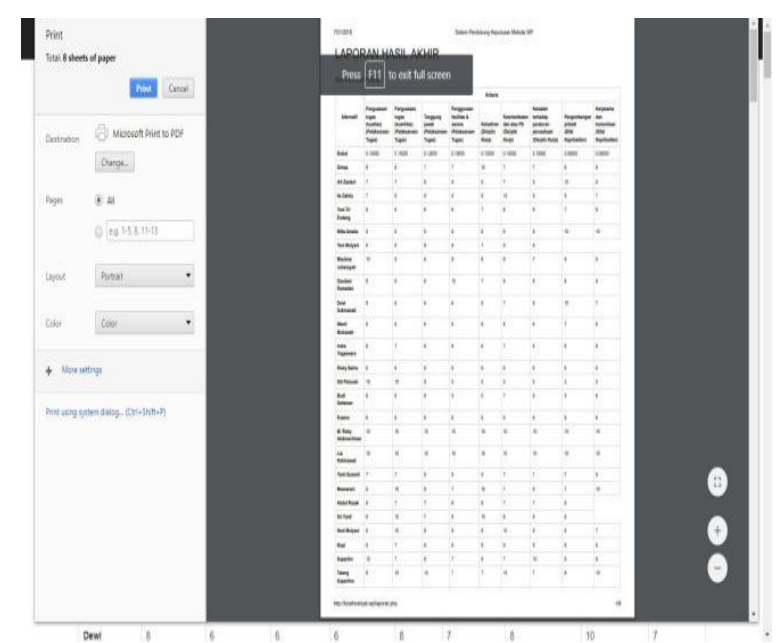

Gambar 31. Tampilan Halaman Cetak Laporan

\section{KESIMPULAN}

Dalam pembahasan kesimpulan menjawab permasalahan yang ada dan berisi mengenai kelebihan Sistem Pendukung Keputusan yang dibangun dengan menerapkan Metode Weighted Product sebagai berikut:

1. Sistem pendukung keputusan memberikan kemudahan bagi pihak manajemen dalam melakukan penilaian kinerja terhadap Pramuniaga sesuai dengan standar/kriteria yang telah ditentukan.

2. Sistem Pendukung Keputusan evaluasi kinerja Pramuniaga berhasil dibangun menggunakan Web Programming berbasis objek.

3. Metode Weighted-Product yang diterapkan sangat tepat dan relevan untuk menghitung peringkat atau perangkingan dari kinerja Pramuniaga di Toserba Yogya Ciwalk.

\section{DAFTAR PUSTAKA}

[1] Huber, G. P. (1980). Managerial Decision Making. Glenview: Scott, Foresman and Co.

[2] La Bella, L. (2017). Getting a Job in the Retail Industry. New York: The Rosen Publishing Group, Inc.

[3] Latif, L. A., Jamil, M., \& Abbas, S. H. (2018). Buku Ajar: Sistem Pendukung Keputusan Teori dan Implementasi. Yogyakarta: Penerbit Deepublish.

[4] Nofriansyah, D., \& Defit, S. (2017). Multi Criteria Decision Making (MCDM) pada Sistem Pendukung Keputusan. Yogyakarta: Penerbit Deepublish.

[5] Nofriansyah, D. (2014). Konsep Data Mining Vs Sistem Pendukung Keputusan. Yogyakarta: Penerbit Deepublish.

[6] Prasetyadi, C. W. (2017). Komunikasi Penjualan: Menuju Pramuniaga Juara. Jakarta: PT. Elex Media Komputindo.

[7] Reynolds, G. W. (2016). Information Technology for Managers $\left(2^{\text {nd }}\right.$ ed.). Boston: Cengage Learning.

[8] Sari, F. (2018). Metode dalam Pengambilan Keputusan. Yogyakarta: Penerbit Deepublish.

[9] Simon, H. (1997). Administrative Behavior: A Study of Decision Making Processes in Administrative Organizations ( $4^{\text {th }}$ ed.). New York: The Free Press.

[10] Stair, R. M., \& Reynolds, G. W. (2016). Fundamentals of Information Systems $\left(8^{\text {th }}\right.$ ed.). Boston: Cengage Learning. 